\title{
Developing Analytical and Observational Approach in Undergraduate Learners
}

\author{
S. S. Patwardhan ${ }^{1}$, A. Sharma ${ }^{2}$, S. A. Mani $^{3}$, S. R. Chawade ${ }^{4}$ \\ ${ }_{1,2,3,4}$ Department of Science and Humanities, K. J. Somaiya College of Engineering, Vidyavihar, Mumbai-400077, \\ Maharashtra, India \\ lsurenpatwardhan@somaiya.edu \\ 2archana.sharma@somaiya.edu \\ ${ }_{3 \text { santoshmani@somaiya.edu }}$ \\ shrikantchawade@somaiya.edu
}

\begin{abstract}
A learning mechanism was proposed to monitor student's on-going solitary as well as social learning strategies. In addition, the student's conceptual learning problems and learning styles were also considered for providing this effective learning activity. The authors experimented with internal assessment component of the undergraduate engineering curriculum for such learners by giving them various technical topics and asking for presentation in the form of a poster. The novelty with this technique is the entire process of learner's submission of the poster (group activity), viva based on the topics of individual assessment, feedback of the peers, and reviews from the teachers. The idea behind this activity was to go beyond the classroom teaching, develop the understanding of the applicability of the topic and self-learning. The facilitator has complete flexibility in configuration of the entire process of this internal assessment. The efficacy of this assessment technique using Poster presentation was evaluated using metrics like attractiveness, creativity, understanding the concept and viva based on the topic. The authors also conducted a survey of the learners to understand the effectiveness of this assessment tool implied. On an average, $90 \%$ learners from a randomly collected feedback sample set agreed that this is an effective tool to enhance their analytical skills and coordination with their peers.
\end{abstract}

Keywords: active learning, critical thinking, internal assessment; technology-enhanced learning, assessment tool

\section{INTRODUCTION}

In earlier days, teachers used to teach in a formal and stereotypical ways. Often, the learners could not understand what was taught in the class and were expected to reproduce the understanding at the time of test/examination. Learners were silent observers and were not able to make any logical questioning or independent thinking of their own. Now in today's world, the learner's brain cannot be regarded as an empty vessel that can be filled by facts and figures. They are now expected to use various resources available from the media to get learning experience from all sides. Education is now conceived as a process of an interaction and communication using technology enhanced learning. The modern teacher has to guide or facilitate the learner's development. The teacher as a facilitator is required to inspire/motivate the leaners in their thirst of knowledge and understanding skills (Berman, 2008). The learning outcomes require the intellectual process of actively and skillfully analyzing, applying, observing, and evaluating a given problem that helps in developing critical thinking skills in the engineering undergraduate learners (Bonwell, 1996, Johnson and Johnson, 1999).

Two significant activities that could be incorporated in the classes easily and are very effective: writing/presentation based on a given topic and learning through solving problems (Wongwatkit et al., 2016). In the proposed writing or presenting activity, learners search information on the given topic, analyse the content critically, analyse the reasoning incorporated in the information, and then articulate their thoughts (Alfrey and Cooney, 2009). Thus, one such method to implement is writing for reflection, where rubrics can be provided for evaluating open-ended problems (Forsyth and McGovern, 1983). The feedback is an important step in refining thinking and cognition. The facilitator can also provide feedback to help learners revise their initial written reflections (Forsyth, 2006). The purpose of this study is to assess the development of critical thinking skills in undergraduate engineering learners. Analytical and observational approach is also an essential component for undergraduate learner in engineering disciplines (Ledlow, 2001). As per literature survey there are several of internal assessment techniques for developing this approach but many are not able to enhance the above mentioned skills in the learner (Topping and Keith, 2000). Critical thinking has always been considered as a necessary learning outcome for all learners and essential for their academic and career success (Kollar, Ingo, and Fischer, 2010). There are many challenges to develop a comprehensive approach to teaching and assessing learner's critical thinking (Reynolds K, 2019). It is rather a 
challenge to adapt new learning activities/techniques to enhance/assess the learner's analytical and observational approach towards a given problem. Thus, some new learning support systems can be introduced by providing learning suggestions/activities to the individual learners as well as their peers (Ralston and Bays, 2015). The authors decided to find and implement a technique which is suitable to first year engineering learners in all respect and give wide spectrum of peer group learning with application in emerging technology (Sharma and Potey, 2018). A topic based on syllabus with some application was assigned to group of learners well in advance and they were asked to present their understanding in form of poster within one hour duration only. The group was expected to share their understanding by presentation and viva based on the given topic. The authors conducted survey of learners to evaluate the effectiveness of this technique and found that many learners agreed that their analytical and observational approach were developed.

\section{MOTIVATION AND PURPOSE}

The authors teach Engineering Physics to the First year engineering learners. Due to traditional teaching involving chalk and board method, most of the learners remain compliant learners and remain inactive during the physics lectures of an hour. Many times learners are not able to understand the theoretical concepts during lectures and therefore, cannot solve problems based on that. For example, we found learners were almost in doubt as to apply which particular interference condition in solving problems on thin film interference if transparent films with different refractive indices are involved. Hence, it needs more focus and one to one interaction with learners. Therefore, the authors felt the need to incorporate active learning beyond the classroom teaching. At the same time the authors also wanted to inculcate critical thinking skills such as interpretation, analytical and inference in their learners. The motives behind using this strategy are listed as follows. (i) To create dynamic classroom through active learning strategy (ii) To promote critical thinking and analytical approach towards the given problem (iii) To encourage individual participants to generate new ideas of solving problems (iv) To develop interpersonal relation through discussions with the peers (v) To change to student centric learning process.

Out of many other strategies available, authors decided to go for a new technique for assessing learners' performance based on the group activity as well as one to one performance. This activity helps the learners to learn, to think about the problem, to analyse different aspects of it and then how to present it. These kinds of activities are possible when the learners are thinking individually and share with their peers. When they think alone, they create their own idea. When they do it in the group, they share their ideas with other learners. This increases the ability to communicate or present their idea in a convincing way. When learners discuss in a group, each and every student shares their thoughts, the number of ideas becomes more.
Keeping this point in mind, authors decided to assess them on the basis of their group performance (Poster presentation) as well as their own idea of understanding the concept (Viva) based on the topic given.

\section{PLAN AND IMPLEMENTATION OF THE ACTIVITY}

As this assessment tool involves group activity, clearly there were two parts in the assessment i.e. individual assessment and group assessment. Learners were already intimated about the activity at the beginning of semester. Idea of the activity and rubrics for evaluation was already mailed to the learners. The first phase was the poster making and second phase was the viva of individual learners based on the assigned topics. For poster making session, a group of three learners was formed and a topic was assigned to them. The topic assigned doesn't get repeated for a branch. Details of the activity planned branch wise for both the semesters have been shown in Table 1 .

A stipulated time of two weeks was provided to them for the preparation of the topics for making the poster (minimum size given is A3 size). Instructor cleared the doubts of learners regarding the activity in the lecture hours. Teaching-learning activities on the concepts involved in the topics offered for presentations were conducted using flipped classroom before the beginning of this assessment. This activity was conducted during the $6^{\text {th }}$ week of the semester; once the learners are through with their mid-term test. On the scheduled date of the poster making session, learners were ready with their drawing materials to put up their understanding of the concepts in the poster form. No resource materials/readymade printouts/mobile phones were allowed during one hour of the activity. This activity was conducted in the spirit of examination. The instructor went around the class to make sure that all the learners are involved actively in the ongoing activity by asking them random questions on their topic. The posters were collected from the learners after 1 hour. The viva for the poster was conducted in the $10^{\text {th }} / 11^{\text {th }}$ week of the semester before the end-term test begins. The learners were assessed on the individual performance in this Q \& A session. They were expected to explain the concept presented in the poster. The learners were assessed based on their contribution in the poster making (group performance) as well as the question-answer session reflecting their individual performance.

\section{ASSESSMENT STRATEGY}

Rubric has to be designed keeping activities in mind, whether it is an individual or group assessment and also how learners showcase their skills. Each part of the assessment is divided into 3 levels namely, Excellent (highest score), Average (middle score) and Improvement needed (lowest score). Details of the requirements for attaining specific level of assessment are clearly mentioned in second and third columns of table 2 along with the range of marks allotted. Titles of the columns mention whether it is individual assessment or group assessment and total marks allotted to that particular part. Before the 
viva, learners were suggested to work out on strengths and weaknesses of each other's poster. For this, all learners were asked to keep a photograph of their completed poster, which could be shown to peers for peer review. Performance indicator depends upon whether learners have performed assigned activities without help or with help of their peers. If some learner is not able to answer any question in the viva, then there was a provision of help from other learners but with the marks penalty (he will be graded according to lowest level). At the end, group marks are assigned to every learner of the group when they are able to explain the assigned topic of the poster clearly with better understanding and their contribution in the poster making. The evaluation of the poster was done based on the performance indicators given in Table 2. Number of questions asked for the viva varied from 10 to 20 based on learner's response and extent of the topic.

Table 1. Plan for making, presenting and assessing poster

\begin{tabular}{|c|c|}
\hline & \\
\hline Class & F.Y.B Tech \\
\hline Semester & $\begin{array}{l}\text { I (August 2018-December } \\
\text { 2018) } \\
\text { II (January 2019 - May 2019) }\end{array}$ \\
\hline Name of the Course & Engineering Physics \\
\hline Nature of the Course & $\begin{array}{l}\text { Experimental, Analytical, } \\
\text { Conceptual }\end{array}$ \\
\hline Branch & $\begin{array}{l}\text { Semester I: Electronics, Electronics } \\
\text { and Telecommunication, Mechanical } \\
\text { (Division B) } \\
\text { Semester II: Computers, IT, } \\
\text { Mechanical (Division A) }\end{array}$ \\
\hline $\begin{array}{l}\text { Background of the } \\
\text { activity }\end{array}$ & $\begin{array}{l}\text { This is an Internal assessment } \\
\text { component (IA-1: Poster presentation } \\
+ \text { Viva) that has been designed in the } \\
\text { curriculum for F. Y. B. Tech } 2019 . \\
\text { This activity is administered in the } \\
\text { week } 6 \text { of the odd/even semester, } \\
\text { after the Mid -term test ( } 40 \% \\
\text { syllabus is done). }\end{array}$ \\
\hline Objectives & $\begin{array}{l}\text { 1. We plan to test the understanding } \\
\text { of learners by making poster } \\
\text { presentation on a given topic. } \\
\text { 2. This activity increases the scope of } \\
\text { exploring various resources available } \\
\text { for the given topic. } \\
\text { 3. It gives a clear idea to the } \\
\text { instructor about the level of student's } \\
\text { learning and understanding of the } \\
\text { concept. } \\
\text { 4. It also helps the learners to remove } \\
\text { gaps in the understanding by } \\
\text { collaborative learning. (Think-Pair- } \\
\text { Share). } \\
\text { 5. To make them participate actively } \\
\text { for the in-class activity. }\end{array}$ \\
\hline Activity & $\begin{array}{l}\text { Group activity (Poster presentations) } \\
\text { Individual performance (Viva) }\end{array}$ \\
\hline Topic & Portion of the Mid-term Test covered \\
\hline $\begin{array}{l}\text { Duration for poster } \\
\text { creation }\end{array}$ & 1 hour \\
\hline Total marks & 10 \\
\hline $\begin{array}{l}\text { No. of learners in a } \\
\text { group }\end{array}$ & 3 \\
\hline No. of groups & 115 groups per semester \\
\hline
\end{tabular}

The slow learners and the continuous absent students were given comparatively easy topics for the presentations. They were also provided with extra study materials by the facilitators to help them make better presentations of the topics assigned. An extra lecture was also conducted on how to make effective presentations.

Table 2. Assessment grading rubrics (10 marks)

\begin{tabular}{|l|l|l|}
\hline $\begin{array}{l}\text { Performance } \\
\text { Indicator }\end{array}$ & $\begin{array}{l}\text { Poster Making } \\
\text { (Group activity- } \\
\text { 5 Marks) }\end{array}$ & $\begin{array}{l}\text { Viva } \\
\text { (Individual } \\
\text { Performance- } \\
\text { 5 Marks) }\end{array}$ \\
\hline Excellent & $\begin{array}{l}\text { 1. Learners identify the } \\
\text { purpose of including all } \\
\text { complexities and has } \\
\text { thorough understanding } \\
\text { of the topic } \\
\text { 2. Complete and } \\
\text { accurate analysis } \\
\text { supported by relevant } \\
\text { evidences and } \\
\text { examples, Articulated } \\
\text { significant, logical } \\
\text { implications. }\end{array}$ & $\begin{array}{l}\text { Learner able to } \\
\text { explain more than } \\
\text { 70\% of the topic } \\
\text { related } \\
\text { questions and } \\
\text { analyze the problems } \\
\text { given based on the } \\
\text { understanding } \\
\text { presentation of all } \\
\text { relevant assumptions } \\
\text { and points of view. } \\
\text { (4-5) }\end{array}$ \\
$\begin{array}{ll}\text { 1. Identifies the purpose } \\
\text { of including all the } \\
\text { complexities but } \\
\text { insufficient information } \\
\text { about the topics. } \\
\text { 2. Analysis that is not } \\
\text { well supported by } \\
\text { evidences or examples, } \\
\text { accurate information but } \\
\text { could not provide } \\
\text { logical implications } \\
\text { 3. Fair presentation of } \\
\text { most of the relevant } \\
\text { assumptions and points } \\
\text { of view. } \\
\text { (2-3) }\end{array}$ & $\begin{array}{l}\text { Learner able to } \\
\text { explain 40-70\% of } \\
\text { the topic related } \\
\text { questions and could } \\
\text { analyze the problem } \\
\text { given based on the } \\
\text { understanding only } \\
\text { after providing some } \\
\text { hints } \\
\text { (2-3) }\end{array}$ \\
\hline Average & \\
\hline
\end{tabular}




\begin{tabular}{|l|l|l|}
\hline $\begin{array}{l}\text { Needs } \\
\text { Improvement }\end{array}$ & $\begin{array}{l}\text { 1. Not conversant with } \\
\text { all the complexities } \\
\text { involved, inaccurate or } \\
\text { incomplete information } \\
\text { about the topic } \\
\text { 2. Poor analysis not } \\
\text { supported by any } \\
\text { evidence or explanatory } \\
\text { example }\end{array}$ & $\begin{array}{l}\text { Absent for the viva, } \\
\text { able to answer less } \\
\text { than 40\% of the } \\
\text { topic related } \\
\text { questions and could } \\
\text { not analyze the } \\
\text { problems given } \\
\text { based on the } \\
\text { understanding even } \\
\text { importance of the topic } \\
\text { assigned. } \\
\text { after providing } \\
\text { some hints } \\
(1-2)\end{array}$ \\
\hline
\end{tabular}

\section{5. FEEDBACK FROM THE LEARNERS}

The authors conducted a survey with learners to evaluate efficacy of the applied internal assessment (IA Component) tool. The purpose of this study was to assess the development of critical thinking skills in undergraduate engineering learners and to enhance the analytical and observational approach of the learners. This study was conducted using a feedback questionnaire form generated using Google forms. The forms were floated to all the learners and the results were recorded. There were around 190 responses in Semester I from the undergraduate engineering learners of Electronics (ETRX), Electronics and Telecommunication and Mechanical (MECH- Division (B) Branch, while more than 220 responses were obtained from the learners in Semester II from the learners of Computers (COMPS), Information Technology (IT) and Mechanical (MECH- Division A) branch. The feedback presented here is from the same branch of learners of first year engineering. Few questions were posed to the learners for the feedback analysis. The questions are as follows.

Q.1: Was the activity helpful in creating dynamic classroom through active learning strategy Q.2: Did it helped to promote critical thinking and analytical approach towards the given problem? Q.3: Was the activity helpful to encourage individual participants towards new ideas of solving problems Q.4: Did it helped in enhancing interpersonal relation through discussions with the peers?

Fig. 1(a) and 1 (b) indicates the feedback responses from the students of all the branches from Semester I and II for Q. 2 of the feedback form. The graph clearly indicates that the critical thinking skills, analytical and observational approach in the learners improves in the $2^{\text {nd }}$ semester. The options given in the feedback form for all the questions were strongly agree (SA), Agree (A), partially agree (PA) and disagree (D).

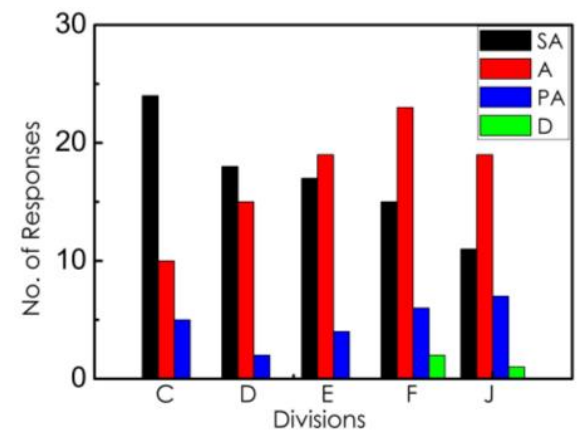

Fig.1 (a): Feedback from ETRX, EXTC and MECH(J) branch from Semester I for Q. 2 posed in the feedback form.

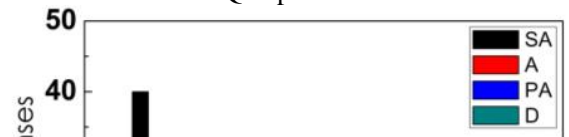

This technique also shows a substantial improvement in peer engagement. The peer engagement (group activity for Poster making) also offered benefits like helping the learner develop critical thinking and problem-solving skills. It also helped to develop the communication, interpersonal and teamwork skills in the learners. The learners spent considerable amount of time for preparation of the poster before the scheduled time. The learners grappled with content and were engaged for more amount of time than in traditional classroom environment. The teachers work was to observe whether all the learners are engrossed in the activity during the entire process of poster making. The teacher played a constructive role in creating good rubrics and summarizing the feedback.

\section{CONCLUSIONS}

With technology, education has taken a whole new meaning. We can prepare students for a lifelong learning process which requires new approaches/technologies to enhance positivity towards education. It's accepted that a well-rounded education is a gateway to personal success. It sets the path of a student to lifelong learning that enables them to succeed in this changing world. Education helps an individual to expand their minds and embrace new ideas and opportunities. Thus this study provides an opportunity to encourage and support the learner's way of critical thinking, and demonstrated a positive impact on the development of learners' analytical and observational approach. Facilitators produced a holistic rubric for the assessment of undergraduate engineering learners. The facilitator continues to refine and enhance course critical thinking experiences. There is a dedicated and sustained effort from the engineering learners to embed in the critical thinking session; also they follow the instruction related to the core course topics that align their critical thinking framework. This type of assessment strengthens and augments on-going strategies that assess the outcomes. This instruction and assessment method continues to improve the critical thinking abilities of undergraduates, which are considered highly important for their skills in analyzing and observing approach toward the problems given. The technique used for developing 
assignments/projects/posters and assessing learner responses fills a gap in the engineering program assessment of critical thinking. The teacher needs to discuss the feedback in class for learner's benefits. The authors plan to experiment with Peer assessment tool for peer ratings and peer rankings as part of their future work.

\section{ACKNOWLEDGEMENT}

The authors would like to thank Prof. (Dr.) Sridhar Iyer, Dr. Veenita Shah and Dr. Gargi Banerjee, IIT Bombay and their team for their valuable inputs and sharing their knowledge and expertise.

\section{REFERENCES}

[1]. Berman S. (2008) Thinking strategies for science, grades 5-12, 2nd ed., Thousand Oaks: Corwin Press.

[2]. Bonwell C. C., (1996)"Enhancing the lecture: Revitalizing a traditional format," New directions for teaching and learning, vol. 67, pp. 31-44.

[3]. Johnson D. W. and Johnson R. T., (1999) Learning together and alone: Cooperative, competitive, and individualistic learning, 5 th ed. , Boston: Allyn \& Bacon.

[4]. Wongwatkit C. , Hwang G.-J., N. Srisawasdi and P. Panjaburee, (2016) Enhancing Learning Attitudes and Performance of Learners in Physics with a Mastery Learning Mechanism-based Personalized Learning Support System, IEEE 16th International Conference on Advanced Learning Technologies.

[5]. Alfrey K. and Cooney E. (2009) Developing a rubric to assess critical thinking in assignments with an open-ended component. Paper presented at the American Society for Engineering Education Annual Conference and Exposition, Austin, TX.

[6]. Forsyth D. and McGovern T.V.,(1983) An introduction to group dynamics, Monterey, California: Brooks/Cole Publishing Company.

[7]. Forsyth D., (2006) Group Dynamics Belmont, 4th ed., CA: Thomson Wadsworth.

[8]. Ledlow S., (2001) Using Think-Pair-Share in the college classroom, Center for Learning and Teaching Excellence, Arizona State University, 2001.

[9]. Topping and Keith J., (2000) "Formative peer assessment of academic writing between postgraduate learners." Assessment \& evaluation in higher education 25.2: 149-169.

[10]. Kollar, Ingo, and Frank Fischer. (2010) "Peer assessment as collaborative learning: A cognitive perspective." Learning and Instruction 20.4: 344-348.

[11]. Reynolds K, (2019) "Audience Analysis: Learning About Learner Motivations and Instructional Preferences" (2019). Library Faculty Research. 34.

[12]. Ralston P. A. and Bays C. L. (2015) "Critical Thinking Development in Undergraduate Engineering Learners from freshman through Senior Yearm A 3-Cohort Longitudinal Study", American Journal of Engineering Education, Volume 6, Number 2.

[13]. Sharma D. and Potey M. (2018) "Effective Learning through Peer Assessment Using Peergrade Tool." IEEE Tenth International Conference on Technology for Education (T4E). IEEE, 2018. 